
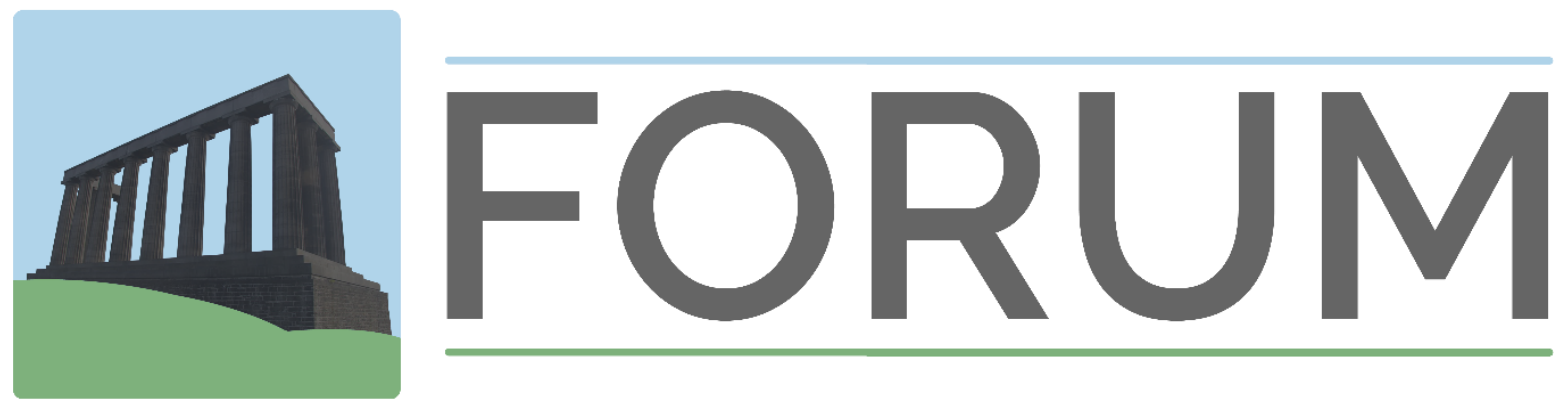

University of Edinburgh

Postgraduate Journal of Culture and the Arts

Issue 32 | Autumn 2021

Title

Growing Up during the Great Depression in Aotearoa New Zealand. A Comparative Study of Shonagh Koea's The Kindness of Strangers (2007) and Renée's These Two Hands (2017)

Author

Marine Berthiot

Publication

FORUM: University of Edinburgh Postgraduate Journal of Culture \& the Arts

Issue Number 32

Issue Date

Autumn 2021

Publication Date

$01^{\text {st }}$ October 2021

Editor

Kathleen Stevens

FORUM claims non-exclusive rights to reproduce this article electronically (in full or in part) and to publish this work in any such media current or later developed. The author retains all rights, including the right to be identified as the author wherever and whenever this article is published, and the right to use all or part of the article and abstracts, with or without revision or modification in compilations or other publications. Any latter publication shall recognise FORUM as the original publisher. 


\title{
Growing Up during the Great Depression in Aotearoa New Zealand. A Comparative Study of Shonagh Koea's The Kindness of Strangers (2007) and Renée's These Two Hands (2017)
}

\author{
Marine Berthiot \\ University of Edinburgh
}

New Zealand writers Shonagh Koea (1939 - ) and Renée (1929 - ) grew up during the Great Depression and its aftermath. Their memoirs challenge the official rewriting of New Zealand history when both authors claim that they belong to the working class. Indeed, New Zealand has long constructed itself as a class-free nation, contrary to the UK. The traumatic experiences which occurred when the writers were young affect them on two levels. They impact them personally, but also culturally. Not only has the working class often seen its history erased and silenced, but Renée also testifies to the part played by colonisation and segregation in the cultural trauma of the Māori community.

\section{Introduction}

Shonagh Koea and Renée grew up in Aotearoa New Zealand during the Great Depression. They were raised in working-class families in a country that has long been considered as a class-free nation, following Irish and Scottish settlers' dreams of building a more egalitarian society than they had experienced in the UK and under British rule in the nineteenth century (Olssen 50). When Renée and Koea depict their childhood in working-class environments during the Great Depression, they testify to a cultural trauma which belongs to their class and which is twice unspeakable: on a personal level, due to girlhood trauma; on a national level, as the history of the working class has been violently repressed in New Zealand.

Renée (1929-) is a playwright, novelist, and poet from Māori descent and from the LGBTQ+ community who grew up in Napier at a time when segregation was practised in New Zealand. Damon Ieremia Salesa argues that "[m]uch of New Zealand's colonial history was characterised by attempts to institute a bi-racial code, attempts that were, in some areas, remarkably successful" (22). From the 1920s to the beginning of the 1960 s, segregation was 
practised in some areas, barring Māori from sharing buses, restrooms, schools, residential areas, movie theatres, restaurants, and maternity wards with white settlers (Bartholomew n.p.). Shonagh Koea (1939-) is a novelist of Pākeha $\bar{a}^{1}$ descent who was constantly displaced in and around Hastings as a child due to her father's regular unemployment and gambling habits. Her memoir is a testimony of complex childhood trauma due to verbal, emotional, and physical abuse at the hands of her father. The life writing texts of these authors-The Kindness of Strangers: Kitchen Memoirs by Shonagh Koea (2007), and These Two Hands: A Memoir by Renée (2017) — depict the impact of the international recession on their education as girls.

In this context, I will answer the following question: to what extent do Koea and Renée reinscribe their girlhood trauma into the cultural trauma of their class and their communities? To do so, I will first apply a Just Therapy approach to the concept of "dysfunctional families." I will then excavate New Zealand's working-class history from censorship. Finally, I will explore the way women life writers connect their ars poetica with their girlhood trauma.

\section{Changing Perspective on Dysfunctional Families Using a Just Therapy Approach}

Reading New Zealand literature through the lens of Just Therapy is not only culturally sensitive; it also circumvents Western temptations to read autobiographical texts through a psychoanalytic lens. Laura Marcus warns against this trend in reception theory as it simplistically equates writers with analysands and gives readers the power of psychoanalysts to formulate "diagnoses." Indeed, analysts and readers are "both the receivers and the interpreters of life history" (262-263). To avoid this pitfall, I offer to read Renée's and Koea's memoirs via Just Therapy theory which provides an accountable methodology as it is a New Zealand-based form of family therapy and is respectful of gender, class, sexual orientation, and ethnicity. Just Therapy was founded in the 1990s by Charles Waldegrave of Pākehā descent and Kiwi Tamasese of Samoan descent, at the Family Centre in Wellington. The foundation stone of Just Therapy lies in "action-reflection" and team-work (Waldegrave and Tamasese 96), allowing therapists to decolonise the mental health sector by voicing their concerns regarding gender and racial approaches to family therapy. Kiwi Tamasese explains:

\footnotetext{
$1 \quad P \bar{a} k e h \bar{a}$ is the term originally used by Māori to refer to British colonisers and their descendants. Pākehā are the majority ethnic group in Aotearoa New Zealand (Stats NZ/Tatauranga Aotearoa 2019) as it is a heterogeneous term which incorporates many ethnicities, especially white Europeans.
} 
I think of colonization, no longer with the might of the sword, no longer with the decimation through disease, but through the gentle conversation of a therapist assuming the rightness of her/his value system, or, more dangerously, assuming that the discipline is scientific, therefore value-free, therefore intercultural and international. (101)

Tamasese exhorts therapists and researchers to challenge the Western theories and methodologies they have been trained to apply because they perpetuate the colonial enterprise onto minorities, excluding them from the spheres of power and devaluing their knowledge systems. Western discourses marginalise and other Indigenous people, migrants, refugees, and women in general. In the case of mental health, these theories further subjugate patients into narratives of failure, making patients believe they cannot succeed in any of their familial and social roles. New Zealand's political ambivalence as a settler nation participates in implementing social inequalities as it sits between postcolonialism and decolonisation (Gunew 24). Despite implementing a bicultural policy since the 1980s, Māori still suffer from the effects of colonisation in several fields including education, employment, health, and justice (Kennedy). For example, Renée testifies that, in the 1930s and 1940s, renting signs claimed "No Dogs, No Māori" (16); her mother was forbidden to buy alcohol as Māori were treated as children in their own country, depriving them of their rights and their sovereignty (Meek 38); and she was discriminated against on her first day at school on account of her skin colour. By investigating the social roots of her childhood trauma, Tamasese and Waldegrave would contest the Western diagnosis of "family dysfunction" in her case; rejecting this concept in favour of an analysis of the part played by segregation and the recession in subjugating Renée's family.

Charles Waldegrave explains that the therapist, like the reader, is situated as an active witness in patients' trauma telling:

The therapist listens for the story and helps its articulation. She or he helps people to say the difficult bits, go back to the missed-out bits, ensuring its totality and all its pain. Then in return for the story, the therapist offers a reflection deeply from the family's belonging. (99)

As a witness, the therapist/reader is accountable for the testimony they attend as they participate in its enunciation by encouraging the survivor in delivering her/his story until the end. In a Pacific-centred approach, the therapist/reader welcomes the patient/writer's story like a gift and offers an analysis/reading of the testimony as a counter-gift. Renée's memoir opens 
with a sarcastic comment on her own birth: "I was born in Napier on Friday, 19 July 1929, and the world went into a deep depression. Then Napier fell down. Two years after that my father shot himself. He was from Gore. Drama didn't just follow me, it came out and met me with a big tah-dah" (11). Renée offers here a dramatic interpretation of her birth as she claims to be the triggering agent of the 1929 Wall Street crash, of the 1931 Hawkes' Bay earthquake which destroyed her hometown and its surroundings and killed 258 people (Simon 17), and of her father's suicide, as if she felt responsible for this last event. The suffering she felt growing up in the aftermath of these three disasters is never fully expressed, but it is hinted at in a letter inserted in the memoir. This letter was written to Renée by a therapist. It excavates what Renée leaves in the interstices of her unconnected memories: "the (perhaps) never recognised despair of a little girl, who was precociously mature, but who was also 'secretly' depressed in her deprivation and anxiety - somewhere, very deeply, quietly despairing - amidst all of the surface 'drama' and 'bossy' responsibility” (266). This mise en abyme reflecting an intradiegetic therapist/reader's analysis of her childhood trauma allows Renée to warn extradiegetic readers of feelings that she cannot express herself. Indeed, the letter ventriloquises aspects of Renée's personality which she cannot fathom as they are intermingled with her childhood trauma. Inserting the word of a therapist reading right through Renée/her patient not only gives voice to a figure of authority in the field of trauma but also highlights the fact that girlhood trauma deauthorises Renée of some aspects of her life. Consequently, Renée uses ventriloquism as an alternative means of communication to reclaim the narrative of her life in her memoir.

In The Kindness of Strangers, Shonagh Koea constructs herself as a relational being, creating a constant dialogue with her readers, as she addresses them directly, especially when she comments on the recipes she includes in her memoir. The recipes have a symbolic value as they recall the meals benevolent people offered her amid chaos. Koea associates meals eaten at home during her childhood with domestic violence, humiliation, and degradation as her father demonstrated an erratic and vicious behaviour towards his wife and daughter. In contrast, the recipes Koea gives her readers, accompanied by personal cooking tips, bring comfort in times of trauma as they remind her of the generosity and empathy of those who witnessed her distress and gave her a hand when growing up. In exchange, Koea expects readers to reorder and assemble the fragments she formulates about her past and disseminates throughout her text. Her narrating "I" testifies to Post-Traumatic Stress Disorder-following her complex childhood trauma - as she describes the nightmares, hallucinations, and anxiety crises she 
regularly experiences as an adult. Therefore, her trauma narrative echoes Leigh Gilmore's comment on the hardship life writing represents for trauma survivors:

Anxiety over looking back suffuses the history of self-representation. Like Lot's wife fleeing Sodom and Gomorrah or Orpheus departing Hades with Eurydice, autobiographers who look back sometimes represent themselves as risking their tenuous hold on the present and their hope for a future. ("Witnessing" 158)

Koea's girlhood trauma can be found in the subtext of pain, in the gaps between the different fragments of her testimony, and in her reluctancy to describe scenes of violence, preferring to allude to their repetitive pattern and hide them under the guise of fiction. Indeed, Koea constructs her authorial posture as a model of resilience. As G. Thomas Couser notes, "at its best, life writing does not register preexisting selfhood, but rather somehow creates it. [...] [I]n writing one's life one may bring a new self into being. If this is true, then in reading life narrative, we witness self-invention" (13-14). Koea transforms the nightmare of her childhood into a literary apprenticeship, comparing her fate to her hometown Hastings, which used art to rebuild from the rubbles of the 1931 earthquake. As in a self-help manual, Koea therefore empowers her readers with active tips with which to face and overcome anxiety and past selfshattering experiences. A Just Therapy approach shows that Koea's dysfunctional family was the result of factors external to the home, even if the trauma occurred at home and there were no manifestations of abuse outside of home. Malcolm McKinnon coined the term "the Broken Decade" to refer to the damage the 1929 economic crisis and the 1931 earthquake had on New Zealanders in the 1930s. This era indeed triggered long-term ripple effects on the patriarchy, destabilising men's power inside their families due to regular unemployment and financial instability.

\section{Excavating New Zealand's Working-Class History from Censorship}

Koea and Renée note that the autobiographical accounts of their lives are to be read as memoirs, as they testify to historical events they witnessed, such as the 1981 Springbok Tour. For Christiane Lahusen, "memoir is distinct from autobiography in that it characteristically involves inserting an individual life's story into a larger context of public or historic consequence" (626). The memoir form allows both writers to insist on the role they played in the development of New Zealand Literature. By recording their memories, Koea and Renée 
thus develop another perspective on history, writing her story inside the narrative of their (literary) nation. However, as Lahusen notes, "[t]he memories of childhood contained [in a memoir] are usually colorless, being mostly restricted to short descriptions of the external circumstances of childhood and youth" (629), which means the choice of memoir writing is pertinent for Koea and Renée as memoirs tend to minimise the role of childhood, preferring to focus on the adult's life. Readers' expectations of memoirs would therefore consider the writers' developmental years as minor, which would be paradoxical in the case of Renée and Koea as both authors suffered from complex childhood trauma with lifelong repercussions.

Christine Courtois makes a distinction between several forms of trauma. She explains a complex trauma as "a type of trauma that occurs repeatedly and cumulatively, usually over a period of time and within specific relationships and contexts" (412). To survive interpersonal trauma (trauma performed by a member of the family, to whom the child is attached), children develop coping techniques like neurobiological defence mechanisms that affect their memory. For some, memories of childhood abuse can be debatable as "trauma has the potential to alter brain functioning" due to the high level of stress it generates (Cohen et al. 19). The right side of the brain can be damaged, affecting the regulation of emotions and the recording of memories (Siegel 166). Memoir writing thus becomes a form of trial by ordeal as both women life writers feel the need to testify to the abuse they experienced as children while being unable at times to remember it fully (Gilmore "Conclusion" 144). Jane Kilby invites readers to "learn to read for what is not and cannot be said: namely we learn to listen to the silence left by violence" (18). Neither The Kindness of Strangers nor These Two Hands record their writers' lives chronologically. On the contrary, they are composed of fragments that are seemingly unconnected to each other, dismantling essentialist constructions of the self as unified from birth to death (Anderson 4). Readers can therefore find the impact that girlhood trauma left on both writers in the gaps left between their fragmented memories: childhood abuse destroyed them into broken pieces which need to be mended and reassembled.

Writing a memoir gives Koea and Renée the power to downplay the impact childhood trauma had on their lives, focusing instead on the rewriting of their lives inside wider traumas which affect their social class and, for Renée, her ethnic community. By doing so, they participate in the construction of the cultural trauma working-class families endured during the Great Depression. Renée also testifies to the cultural trauma the Māori endured when segregation was the status quo in New Zealand. Jeffrey Alexander defines cultural trauma in these terms: 
Cultural trauma occurs when members of a collectivity feel they have been subjected to a horrendous event that leaves indelible marks upon their group consciousness, marking their memories forever and changing their future identity in fundamental and irrevocable ways. (1)

Koea and Renée's personal accounts of instability and insecurity, as well as food shortages, reveal the way children were affected by the 1929 financial crisis. Both girls grew up hungry, in constant fear for their safety, and with flawed figures of authority. Contrary to the rags-to-riches stories which circulated at the time, praising the valour of male workers who could climb the social ladder, neither Renée nor Koea rose above the class they were born into because they are at the intersection of additional subjugating factors such as gender, sexual orientation, and ethnicity. For Paul Maunder, a historian who participated in the construction of a memorial to working-class strikers in the South Island, "it is [important] to continue to articulate the story of the contribution that working people made, and continue to make, to the system of social democracy, and to identify the forces which [...] wish to silence this story" (142). Maunder, like Koea and Renée, entices readers to respect the habitus of working-class families whose ethics were based on solidarity and generosity and to challenge the New Zealand neoliberal discourse projected onto the poor.

Renée, in particular, excavates this part of history that was suppressed by the State via police violence and home raids. As a result, she intermingles two twenty-first-century discourses into her self-portrait as a child in the 1930s:

We were the Great Unwashed, the kids with snotty noses, dirty clothes, sores, nits, bare feet, rotten teeth, hungry bellies, staring eyes. We weren't attractive. Most of us left school at twelve and did the jobs the haves didn't want to do. We were cheap too. And we needed the work. (134)

This caricatural portrait echoes today's neoliberal campaigns against child poverty in New Zealand and the Occupy Wall Street slogans following the 2008 recession, such as "We are the 99\%" (Durana n.p.). Renée plays with the way today's neoliberals colonially perceive Mãori children as Victorian paupers, while the neoliberal system itself created the 2008 economic crisis which still deprives some children in New Zealand of food, clothes, and educational possibilities. Renée's cynicism towards New Zealand neoliberal discourses on Māori children questions New Zealand's welfare system, implicitly stating that today's management of child poverty is similar to the standards of the 1930s. Renée also denounces 
the "streaming" policies schools practice towards Māori children, leading Māori to be overrepresented in percentages of students leaving school and attending vocational schools (Lee 50; Wang and Collins 2786). She interprets her personal experience of working at age twelve despite her academic abilities and skills as evidence of social and racial determinism. She resents the feeling of injustice she experienced at being rejected from the locus of knowledge. The anger associated with the segregation of knowledge never quite left her and led her to pursue life-long education in different institutions to repair this initial loss of time. Although she did not climb the social ladder, Renée still managed to fight actively against colonial remnants stereotyping the Mâori community and disempowering them in their own country.

Koea's and Renée's memoirs could be labelled as working-class autobiographies, as they are "predicated on work and working life" (Strangleman 151), first as housewives and then as writers, but also on the lifestyle of their class. Despite a historic denial of the existence of social classes in New Zealand (Olssen 45; Maunder 139), Koea and Renée remind their readers of a counter-story that rehabilitates the memory of their generation who grew up destitute during the 1930s and 1940s. Koea constructs her authorial voice as caring for her readers, replicating in her writing the solidarity she experienced from neighbours and extended family during her childhood. She applies the generosity members of her class showed her in times of distress like a soothing balm onto her text, helping her reclaim the concepts of selfrespect and privacy which were denied her by her father. As for Renée, she uncovers "undervalued, ignored or in some cases vilified" events (Strangleman 147) by the dominant version of history. The working-class heritage she honours in her writing career is at the heart of her life writing project. Her representation of the intangible heritage of strikers and demonstrators gives visibility to a history which risks being suppressed from collective memory. Indeed, Homi K. Bhabha warns against selective oblivion in the creation of imagined nations (311). Renée's memoir can thus be read as a counter-discourse to the official omission of the working class in the construction of New Zealand's narrative as a nation.

\section{Mending, Reconstructing, and Framing: Women Life Writers' Ars Poetica and Trauma Telling}

In embedding their accounts of girlhood trauma into cultural traumas which affected their social class and the Māori community, Renée and Koea transform the personal into the 
political in a feminist way. They do so by challenging what Lawrence Jones defined in 1985 as the "One Story, Two Ways of Telling, Three Perspectives"' ideal of autobiographical texts in New Zealand Literature. For Jones, when New Zealand writers compose their lives, they always tell the same story, that of "Man Alone". In this storyline, writers describe their constant fight against a parochial and puritan society which is allergic to art. Male writers tell this story in a realist and "masculine" mode, while women writers tell it in an impressionist and "feminine" mode. As for the three perspectives from which writers can tell their stories, they are temporally marked. Before the 1950s, authors had a "Late Colonial" approach; after the 1950s, they had a "Provincial" viewpoint; and from the 1980s onwards, a "Post-Provincial" conception of their role within New Zealand's society. The problem with such a definition of New Zealand autobiography lies with the fact that Renée and Koea experienced all three eras. They do not construct themselves as "Women Alone" but as relational beings, even at the worst times of childhood abuse. As they disrupt the chronological order of their lives, their account could be perceived as "feminine". Yet, their testimonies cannot be rejected as unrealistic. Otherwise, their life writing could run the risk of being distrusted and charged for litigation (Gilmore "Representing Yourself" 22-23). Finally, their memoirs are polymorphous as Koea inserts recipes and extracts from her novels inside the telling of her life, ostensibly mixing facts and fiction; while Renée plays with the literary material at hand, as one third of her memoir is fictional.

New Zealand women's life writing is essentially hybrid to challenge Western phallocentric, white, middle class, and heteronormative autobiographical canons (Bergland 77; Gilmore "Introduction" 5; Rippl et al. 5-6). Koea and Renée, for example, highlight the healing power of gardening. Recognizing gardening as a form of life writing allows survivors to express their trauma in a language other than words. Koea notes the gardening habit her mother had developed, constantly creating gardens from scratch even though they moved houses every few months. Each time, she would build her own garden of Eden. She came back "home" after work to garden and create an assemblage of colours, fragrances, forms, and sizes, to control the passage of time and arrange space. Yet, her creative power was trespassed on by her husband's violence inside the familial bubble. Renée also notes the relief she feels whenever she starts creating a garden (72-78), paying a lot of attention to the names and symbols of the flowers she plants and taking pride in passers-by's positive comments on her creation. Gardening is therefore a form of land writing which inscribes the signature of the trauma survivors on its conception, giving them back authority over their names and life narratives. 
Eneken Laanes stresses that language does not always necessitate words: "[i]f language lacks modes of representation for helping us make sense of certain events, these events acquire a traumatic nature" (124). In this sense, the analogy between gardening and writing in the telling of trauma offers survivors modes of expression outside of words, as they find tactics to counter trauma in the way they compose with space and time. The power of agency gardening offers them also reverses their positions as they move from passive victims to actors and authors of their own stories.

In composing the autobiographical accounts of their lives, Renée and Koea deliberately create hybrid texts. These Two Hands is compared from the start to a quilt (9), associating life writing to knitting and weaving. As she finished writing it at age 88, Renée composed 88 "patches," although not all these fragments correspond to one year of her life. The idea behind the metaphor of the patchwork is the mending of worn-out fabric that has been torn into bits and pieces. Childhood and cultural traumas turned her life into an overused cloth; but when narrating it, she is able to repair it, give it a new pattern, and connect it to other levels of interpretation. Renée, therefore, insists on the artless aspect of her memoir writing, as the function of a quilt/memoir is "to warm, to comfort, to read under or to read like a book" (9). Like a blanket protecting her from the cold, her memoir protects her from past trauma. Indeed, it is possible to interpret the written patches of her life as bandages applied on wounds. If life writing heals, it is because it re-enacts kete ("basket") weaving, a Māori arts and crafts technique traditionally practised by women (Waretini-Karena 701). This activity can be practised in a group, as when Renée adopted this technique to teach life writing to high school students: "[t]hey worked in groups on their individual projects. Like they were all weaving the same kete" (85-86). Renée made her students work together on the theme of tangi, which means “funeral, grief, mourning” in te reo Māori (Māori Online Dictionary). The teenagers composed personal stories of traumatic events in a caring environment which allowed their peers to support them emotionally. As a writer, Renée debunks the Pākehā myth of "Woman Alone" as she instead emphasises the part played by her whânau ("extended family and close friends") in the creation of her literary work. Renée indeed applies the communal aspect of weaving flax/writing narratives to create a kete/memoir. In These Two Hands can thus be read as a tribute to her whānau, composed of her mother, siblings, first husband, life-long partner, children, mokopuna ("grandchildren”), friends, and colleagues. In his conception of Māori health called he whare tapa whä ("the four-walled house"), Mason Durie (2012) insists on the balance one needs to reach between physical health, mental health, spiritual health, and the 
whänau's health, in order to maintain oneself in good health. To recover from childhood trauma, segregation, and the State's repression of working-class voices, Renée finds comfort and relief in the health of her whänau. As a result, her quilt/memoir composed in old age functions as a protecting companion to face the "night" (9), or Te Kore: the void from which everything and everyone is born and to which everything and everyone comes back when dying, in Māori cosmogony.

Koea's ars poetica can also be defined in relation to trauma and trauma recovery, on a personal level and on a regional level, in relation to Hastings' rebirth after the earthquake. In this context, I posit that Koea develops an art deco literary style to express her childhood trauma. Robin Apollo Simon specifies:

[Hastings] too was rebuilt over the same period [as Napier], but this time largely in the 'Spanish Mission' style. The inspiration here was particularly appropriate: Santa Barbara, California, which had suffered an earthquake in 1925 and which had been rebuilt in this striking manner. (19)

Art Deco's Spanish Mission architectural style reminds Koea not only of the urban landscape of her hometown, but also of her craving to feel at home. Experiences of neglect and abuse, and of constant moves from one house to the next guide her in her quest for safety: "The thought of houses has always fascinated me. Or perhaps it is the idea of a home that does that. When I think of the places I lived when I was a little girl and an older sort of girl they were always sad." Koea's obsession with houses covers most of her memoir, leaving her own story in the corners. Her first experience of the home occurred when she was eighteen. At that time, she was working as a reporter in New Plymouth and she stayed at her aunt Kateanne's home. Her mother's sister welcomed her, cared for her, and protected her from her father's violence. At her death, Kateanne bequeathed Koea a mass of "antiques" which she had accumulated in fifty years of shopping sprees, leaving to her niece the task to classify, list, and recycle these vintage items, dating from the 1920s to the 1970s. Recycling curios is an activity that Koea adapts into her writing style through her attention to details and rare words, which also allows her to freeze time by focusing on one object at a time. This aesthetic approach to domestic life fills in the void left by years of deprivation as a child. Lydia Wevers notes that the "matter of fact narrative tone" (1135) Koea employs to describe lists of objects or her girlhood trauma stands in sharp contrast with "the domestic and familial implications of the recipes, offering comfort and sustenance in the future of a past where none was to be had" (1135). The alliance 
between recipes, creating a dialogue with imagined readers, and her art deco literary stylefocused on abandoned and neglected objects - constructs a pleasant-looking façade over the magnitude of her complex girlhood trauma, a façade which allows Koea to keep her dignity while testifying to the horrors she experienced as a child.

\section{Conclusion}

In The Kindness of Strangers and These Two Hands, Koea and Renée play with the full potential of memoir writing: its format which downplays the role of childhood; its perception as a minor form of life writing in comparison to the canons of male Eurocentric autobiographies; and its political dimension constructing the life of an individual within the history of her nation. Both Renée and Koea experienced diverse forms of abuse as children, such as neglect; verbal, emotional, and physical abuse; racism; segregation; as well as gender and class determinism. Writing memoirs to testify to their girlhood traumas allows them to mention traumatic events without being expected to describe them at length. This genre proves handy as it seems that both authors find difficulties expressing past traumas, especially because of the damage to their memories. Reading a subtext of pain between the lines and in the interstices left between their fragmented life narratives is an accountable approach that readers can develop as a form of respect, empathy, and care for the traumatised children the authors used to be. Both authors also insert their personal traumas into the narration of cultural trauma, excavated from oblivion in the narration of New Zealand as a classless and non-racist nation. Renée especially denounces the segregationist system in which she grew up and which perpetuated inequalities for the Māori population. Applying a Just Therapy framework allowed me to dissect the colonial remnants at stake in the concept of dysfunctional families, highlighting the impact played by the Great Depression and the 1931 Hawkes' Bay earthquake in the education of girls in the 1930s and 1940s. As a result, Renée and Koea build their life narratives through hybrid forms to protect themselves from re-traumatisation, the former mimicking weaving and the latter the art deco architectural style her hometown adopted in its post-earthquake reconstruction. 


\section{Works Cited}

Alexander, Jeffrey C. "Toward a Theory of Cultural Trauma". Cultural trauma and Collective Identity, edited by Jeffrey Alexander et al.. University of California Press, 2004, pp. 130.

Anderson, Linda. “Introduction”. Autobiography. London, Routledge, 2011, pp. 1-17.

Bartholomew, Robert. “Our History of Māori Segregation Needs to Be Part of the Curriculum”. Stuff, 2 May 2021. www.stuff.co.nz/pou-tiaki/300288698/our-history-of-morisegregation-needs-to-be-part-of-the-curriculum.

Bergland, Betty Ann. "Representing Ethnicity in Autobiography: Narratives of Oppression”. The Yearbook of English Studies, vol. 24, 1994, pp. 67-93.

Bhabha, Homi K. "DissemiNation: Time, Narrative, and the Margins of the Modern Nation". Nation and Narration. London, Routledge, 1990, pp. 230-275.

Cohen, Judith A., et al. "The Impact of Trauma and Grief on Children and Families". Treating Trauma and Traumatic Grief in Children and Adolescents. Guilford Publications, 2017, pp. 3-26.

Courtois, Christine A. "Complex Trauma, Complex Reactions: Assessment and Treatment". Psychological Trauma Theory Research Practice and Policy, vol. 41, no. 4, 2014, pp. 412-425.

Couser, G. Thomas. "Introduction”. Memoir: An Introduction. Oxford University Press, 2012, pp. 3-14.

Durana, Gabrielle. "Les slogans d'Occupy Wall Street, de l'or pour les sociologues". Le Plus, Nouvel Obs, 11 Oct. 2011. leplus.nouvelobs.com/contribution/201977-les-slogans-doccupy-wall-street-de-l-or-pour-les-sociologues.html.

Durie, Mason. "Interview. Kaupapa Maori: Shifting the Social”, interviewed by Te Kawehau Hoskins and Alison Jones. New Zealand Journal of Educational Studies, vol. 47, no. 2 , 2012, pp. 21-29.

Gilmore, Leigh. "Introduction. The Mark of Autobiography: Postmodernism, Autobiography, and Genre". Autobiography and Postmodernism, edited by Kathleen M. Ashley et al.. University of Massachusetts Press, 1994, pp. 3-18. 
---. "Represent Yourself". The Limits of Autobiography: Trauma and Testimony. Cornell University Press, 2001, pp. 16-44.

---. "Conclusion: The Knowing Subject and an Alternative Jurisprudence of Trauma". The Limits of Autobiography: Trauma and Testimony. Cornell University Press, 2001, pp. 143-148.

---. "Witnessing Persepolis: Comics, Trauma, and Childhood Testimony". Graphic Subjects: Critical Essays on Autobiography and Graphic Novels, edited by Michael A. Chaney. Madison: University of Wisconsin Press, 2011, pp. 157-163.

Gunew, Sneja. "Who Counts as Human within (European) Modernity?”. Post-Multicultural Writers as Mediators. Anthem Press, 2017, pp. 19-31.

Jones, Lawrence. "The One Story, Two Ways of Telling, Three Perspectives: Recent New

Zealand Literary Autobiography". Ariel, vol. 16, no. 4, 1985, pp.127-150.

Kennedy, Melissa. "Maori Economic Inequality: Reading Outside our Comfort Zone". Interventions, vol. 19, no. 7, 2017, pp. 1011-1025.

Kilby, Jane. "It's All in the Reading: Moving Beyond the False Memory Syndrome Debates". Violence and the Cultural Politics of Trauma. Edinburgh University Press, 2007, pp. $17-42$.

Koea, Shonagh. The Kindness of Strangers: Kitchen Memoirs. Auckland: Random House, 2007, n.p. E-book.

Laanes, Eneken. “Unsayable or Merely Unsaid?”. Haunted Narratives. Life Writing in an Age of Trauma, edited by Philipp Schweighauser et al.. University of Toronto Press, 2013, pp. 123-128.

Lahusen, Christiane. "3.23 Memoirs", translated by Roisin Cronin. Handbook of Autobiography/Autofiction, edited by Martina Wagner-Egelhaaf. De Gruyter Handbook, 2019, pp. 626-635.

Lee, Jenny Bol Jun. Jade Taniwha: Māori-Chinese Identity and Schooling in Aotearoa. Auckland, Raukati Ltd, 2007.

Māori Dictionary. "Kete". maoridictionary.co.nz/search?idiom $=\& p h r a s e=\& p r o v e r b=\& l o a n=$

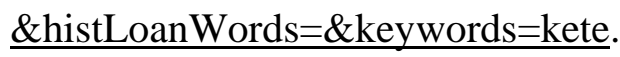


---. "Tangi". $\quad$ maoridictionary.co.nz/search?idiom $=\&$ phrase $=\&$ proverb $=\& l o a n=$ \&histLoanWords=\&keywords=tangi.

Marcus, Laura. "Autobiography and Psychoanalysis". On Life-Writing, edited by Zachary Leader. Oxford University Press, 2015, pp. 257-283.

Maunder, Paul. "The Silencing of Blackball Working Class Heritage, New Zealand”. Heritage, Labour and the Working Classes, edited by Laurajane Smith et al.. Routledge, 2011, pp. 136-144.

McKinnon, Malcolm. The Broken Decade: Prosperity, Depression and Recovery in New Zealand, 1928-39. Otago University Press, 2016.

Meek, Allen. "Postcolonial Trauma: Child Abuse, Genocide, and Journalism in New Zealand". Fourth Eye: Maori Media in Aotearoa New Zealand, edited by Brendan Hokowhitu and Vijay Devadas. University of Minnesota Press, 2013, pp. 25-41.

Olssen, Erik. "The 'Working Class' in New Zealand”. New Zealand Journal of History, vol. 8, no. 1, Apr. 1974, pp. 44-60.

Renée. These Two Hands: A Memoir. Wellington, Mākaro Press, 2017.

Rippl, Gabriele, Philipp Schweighauser, and Therese Steffen. "Introduction: Life Writing in an Age of Trauma". Haunted Narratives. Life Writing in an Age of Trauma, edited by Philipp Schweighauser et al.. University of Toronto Press, 2013, pp.1-18.

Salesa, Damon Ieremia. "Introduction: The Problem of Racial Crossing". Racial Crossings: Race, Intermarriage, and the Victorian British Empire. Oxford University Press, 2011, pp. 1-26.

Siegel, Judith P. "Breaking the Links in Intergenerational Violence: An Emotional Regulation Perspective". Family Process, vol. 52, no. 2, 2013, pp. 163-178.

Simon, Robin Apollo. "Napier, New Zealand: Art Deco Capital of the Southern Hemisphere". London: Apollo, etc. vol. 142, no. 401, 1995, pp. 17-19.

Stats NZ/Tatauranga Aotearoa. "2018 Census Population and Dwelling Counts", 23 Sept. 2019. www.stats.govt.nz/information-releases/2018-census-population-and-dwellingcounts. 
---. "Latest Child Poverty Statistics Revealed”, 24 Febr. 2020. www.stats.govt.nz/news/latestchild-poverty-statistics-released.

Strangleman, Tim. "Working Class Autobiography as Cultural Heritage". Heritage, Labour and the Working Classes, edited by Laurajane Smith et al.. Routledge, 2011, pp. 147159.

Waldegrave, Charles, and Kiwi Tamasese. "Some Central Ideas in the 'Just Therapy' Approach". The Family Journal: Counselling and Therapy for Couples and Families, vol. 2, no. 2, 1994, pp. 94-103.

Wang, Bingyu, and Francis L. Collins. "Becoming Cosmopolitan? Hybridity and Intercultural Encounters amongst 1.5 Generation Chinese Migrants in New Zealand”. Ethnic and Racial Studies, vol. 39, no. 15, 2016, pp. 2777-2795.

Waretini-Karena, Rawiri. "Colonial Law, Dominant Discourses, and Intergenerational Trauma". The Palgrave Handbook of Australian and New Zealand Criminology, Crime and Justice, edited by Antje Deckert and Rick Harris. Palgrave Macmillan, 2017, pp. 697-709.

Wevers, Lydia. "New Zealand". Handbook of Autobiography/Autofiction, edited by Martina Wagner-Egelhaaf. De Gruyter Handbook, 2019, pp. 1114-1142. 


\section{Author Biography}

Marine Berthiot is a third-year PhD student in New Zealand Literature at the University of Edinburgh. Her thesis, supervised by Professor Michelle Keown and Dr David Farrier, deals with the representations of girlhood trauma in New Zealand Literature written by Women Writers. 